\title{
S-Adenosylhomocysteine Hydrolase Inhibitors Interfere with the Replication of Human Immunodeficiency Virus Type 1 through Inhibition of the LTR Transactivation
}

\author{
DIRK DAELEMANS, JOSE A. ESTÉ, MYRIAM WITVROUW, CHRISTOPHE PANNECOUQUE, HEIDI JONCKHEERE, \\ STEFANO AQUARO, CARLO-FEDERICO PERNO, ERIK DE CLERCQ, and ANNE-MIEKE VANDAMME
}

Rega Institute for Medical Research, Katholieke Universtiteit Leuven, Minderbroedersstraat 10, B-3000 Leuven, Belgium (D.D., J.A.E., M.W., C.P., H.J., E.D.C., A.-M.V.), and Department of Experimental Medicine and Biochemical Sciences, University of Rome Tor Vergata, Italy (S.A., C.-F.P.)

Received June 6, 1997; Accepted September 10, 1997

\begin{abstract}
SUMMARY
Various analogues of adenosine have been described as inhibitors of S-adenosylhomocysteine (AdoHcy) hydrolase, and some of these AdoHcy hydrolase inhibitors (e.g., 3-deazaadenosine, 3-deazaaristeromycin, and 3-deazaneplanocin A) have also been reported to inhibit the replication of human immunodeficiency virus type 1 (HIV-1). When evaluated against HIV-1 replication in MT-4 cells, macrophages, or phytohemagglutininstimulated peripheral blood lymphocytes infected acutely or chronically with $\mathrm{HIV}-1_{\text {IIIB }}$ or $\mathrm{HIV}_{\mathrm{BaL}}$ strains, a wide range of adenosine analogues did not inhibit HIV-1 $1_{\text {IIIB }}$ replication for $50 \%$ at subtoxic concentrations. However, they inhibited HIV-1 replication in HeLa CD4 ${ }^{+}$LTR-LacZ cells at concentrations well
\end{abstract}

below cytotoxicity threshold. A close correlation was found $\frac{\mathfrak{\omega}}{\omega}$ among the inhibitory effect of the compounds on AdoHcy hy- $\frac{\text { 응 }}{6}$ drolase activity, their inhibition of HIV-1 replication in Hela $\stackrel{0}{\rightleftarrows}$ $\mathrm{CD}^{+}{ }^{+}$LTR-LacZ cells, and their inhibition of the HIV-1 Tatdependent and -independent transactivation of the long terminal repeat, whereas no inhibitory effect was seen on HIV-1 운 reverse transcription or a Tat-independent cytomegalovirus 으 promoter. Our results suggest that AdoHcy hydrolase and the associated S-adenosylmethionine-dependent methylation mechanism play a role in the process of long terminal repeat transactivation and, hence, HIV replication.
Various analogues of adenosine have been described as inhibitors of AdoHcy hydrolase. AdoHcy hydrolase catalyzes the reversible hydrolysis of AdoHcy to adenosine and L-Hcy (1). Inhibition of AdoHcy hydrolase by adenosine analogues results in an accumulation of AdoHcy, a product inhibitor of methylation reactions that use AdoMet as methyl donor. Methylations of DNA, RNA, proteins, and phospholipids play a crucial role in numerous biological processes (for a review, see Ref. 2). Methylation of eukaryotic and viral mRNA (5'capping) is essential for the maturation of the mRNA and the translation to proteins and hence plays an important role in the virus replicative cycle (2).

\footnotetext{
This work was supported in part by the Biomedical Research Program of the European Union (Biomed 2 Grant BMH4-LT-951634), the Belgian Geconcerteerde Onderzoeksacties (Project GOA 95/5), and a grant from the "Fonds voor Wetenschappelijk Onderzoek (FWO), Vlaanderen" (Grant G.3304396). D.D. acknowledges a grant from the Flemisch Institute supporting Scientific-Technological Research in Industry (IWT).
}

De Clercq et al. (3-6) described the broad-spectrum antiviral activity of AdoHcy hydrolase inhibitors; they exhibit a marked activity against negative stranded (-)-RNA viruses (i.e., Paramyxoviridae, Rhabdoviridae, Arenaviridae), double-stranded ( \pm )-RNA viruses (Reoviridae), and Poxviridae (for a review, see Ref. 3). Because of the close correlation between the antiviral activity and the affinity for AdoHcy hydrolase $(6,7)$, it has been postulated that these inhibitors achieve their antiviral action by targeting the AdoHcy hydrolase.

Previous reports have described the anti-HIV activity of 3-deazaadenosine, an AdoHcy hydrolase inhibitor (8, 9); when evaluated in MT-4 cells, no $\mathrm{IC}_{50}$ values could be obtained due to toxicity to the host cells (4). Mayers et al. (10) reported the activity of 3-deazaadenosine analogues against 3 '-azido-3'-deoxythymidine-resistant strains of HIV-1 in vitro. The mechanism of action of these 3-deazaadenosine analogues as anti-HIV drugs was not explored in detail.

ABBREVIATIONS: AdoHcy, S-adenosylhomocysteine; AdoMet, $S$-adenosylmethionine; $\beta$-Gal, $\beta$-galactosidase; $\mathrm{CC}_{50}, 50 \%$ cytotoxic concentration; C-c ${ }^{3} \mathrm{Ado}$, carbocyclic 3-deazaadenosine; DHCaA, 9-(trans-2,trans-3-dihydroxycyclopentyl)adenine; $\mathrm{c}^{3} \mathrm{DHCaA}, 9-($ trans-2,trans-3-dihydroxycyclopentyl)-3-deazaadenine; c ${ }^{7} \mathrm{DHCaA}, 9-($ trans-2,trans-3-dihydroxycyclopentyl)-7-deazaadenine; DHPA, 9-(2,3-dihydroxypropyl)adenine; Hcy, homocysteine; HIV-1, human immunodeficiency virus type 1; LTR, long terminal repeat; NKO-6-16-3, 3-deaza-3-fluoro-adenosine, NOM14-6-1, 3-deaza-3-chloro-adenosine, NPA, neplanocin A; $c^{3}$ NPA, 3-deazaneplanocin A; PBL, peripheral blood lymphocyte; TAR, transactivation response element; TNF- $\alpha$, tumor necrosis factor- $\alpha$; RT, reverse transcription. 
We investigated a series of adenosine analogues that are known to be AdoHcy hydrolase inhibitors for their inhibitory effects on HIV-1 replication, in vitro reverse transcription, and transactivation of the HIV-1 LTR. Replication of HIV requires the function of the virus-encoded Tat protein, which is a strong activator of gene expression directed by the HIV LTR promoter and functions through interaction with the cis-acting TAR (11-17).

We found a close correlation among inhibition of AdoHcy hydrolase, inhibition of HIV-1 transactivation, and inhibition of HIV-1 replication. Our results suggest that AdoHcy hydrolase plays an important role in the activation of the HIV transcription and can be considered as a suitable target for the chemotherapy of HIV infections by AdoHcy hydrolase inhibitors.

\section{Materials and Methods}

Compounds. Ro5-3335 (18, 19) was synthesized by Wayne A. Spitze and Frantz Victor at Lilly Research Laboratories (Indianapolis, IN). TNF- $\alpha$ was purchased from SanverTech (Boechout, Belgium). NPA, $6^{\prime}-(R)$-methyl-NPA, $6^{\prime}$-( $\left.S\right)$-methyl-NPA, NKO-6-16-3 , NOM-14-6-1, $6^{\prime}-(R)$ - and $6^{\prime}$-(S)-ethynyl-NPA, $6^{\prime}-(R)$ - and $6^{\prime}$-(S)-ethenyl-NPA, and $6^{\prime}-(R)$ - and $6^{\prime}$-(S)-ethyl-NPA were obtained from Dr. S. Shuto, N. Minakawa, and Dr. A. Matsuda (Faculty of Pharmaceutical Sciences, Hokkaido University, Sapporo, Japan). C-c ${ }^{3}$ Ado was from J. A. Montgomery (Kettering-Meyer Laboratory, Southern Research Institute, Birmingham, AL). Both $(R)$ - and $(S)$-DHPA were from A. Holy (Institute of Organic Chemistry and Biochemistry, Czech Academy of Sciences, Prague, Czech Republic). $c^{3}$ NPA was from V. E. Marquez (Laboratory of Pharmacology and Experimental therapeutics, National Cancer Institute, Bethesda, MD). DHCaA and $c^{3} \mathrm{DHCaA}$ were from R. T. Borchardt (Departments of Medical Chemistry and Biochemistry, University of Kansas, Lawrence, KS). KS605 [(+)-9-(cis-4-methoxycyclopenten-2-yl)-adenine], KS606 [(-)9-(trans-2,trans-3-dihydroxy-cis-4-methoxycyclopentyl)adenine], $\mathrm{c}^{7} \mathrm{DHCaA}$, and 5 '-noraristeromycin [(+)-( $\left.1 \alpha, 2 \beta, 3 \beta, 4 \alpha\right)-4$-(adenin-9yl)-1,2,3-cyclopentane-triol] was from S. W. Schneller (College of Science and Mathematics, Auburn University, Auburn, AL). The structural formulae of the compounds are presented in Fig. 1.

Inhibition of HIV-1 transactivation. Tat-dependent transactivation was monitored mainly as described previously (19) with the following modifications. HeLa-tat-III cells [HeLa cells expressing HIV-1 transactivator; kindly provided by Dr. C. A. Rosen (20)] were transfected with pHIVLacZ [kindly provided by Dr. J. J. Maio (21)] or pCMV $\beta$ (22) plasmid DNA by electroporation with an Eurogentec Genepulser (260 V, $1050 \mu \mathrm{F}$, and infinite R). pHIVLacZ contains a $L a c Z$ gene driven by the HIV-1 LTR promoter, and $\mathrm{pCMV} \beta$ expresses the $L a c Z$ gene under control of the cytomegalovirus promoter. For the Tat-independent transactivation assay, $\mathrm{P} 4$ cells [kindly provided by Dr. P. Charneau (23)] were transfected with pHIVLac $Z$ or pCMV $\beta$ plasmid DNA and stimulated with TNF- $\alpha(50 \mathrm{ng} / \mathrm{ml})$. The compound Ro5-3335, previously reported as an HIV-1 LTR transactivation inhibitor $(18,19)$, was used as a reference compound.

The electroporated cells $\left(60 \times 10^{3} /\right.$ well $)$ were incubated in microtiter plates for $24 \mathrm{hr}$ in the presence of varying concentrations of the test compounds. Then, medium was removed by gentle aspiration, and the monolayers were washed with PBS. Cells were lysed with 25 $\mu \mathrm{l}$ of $0.5 \%$ Nonidet P-40, and $\beta$-Gal activity in $20 \mu \mathrm{l}$ of the cell extracts was quantified by a colorimetric assay as described by Sambrook et al. (24). Then, $5 \mu \mathrm{l}$ of cell extract was used to determine total protein content according to the Bradford method (BioRad, Hercules, CA). The $\mathrm{IC}_{50}$ value was calculated as being the inhibitor concentration that reduces $\beta$-Gal expression by $50 \%$.

Inhibition of AdoHcy hydrolase. AdoHcy hydrolase was purified from murine L929 cells using affinity chromatography, and

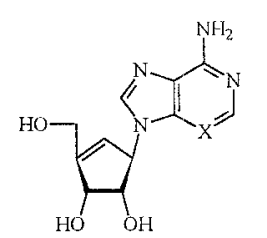

Neplanocin A (NPA) $\mathrm{X}=\mathrm{N}$ $c^{3}$ Neplanocin $A\left(c^{3} N P^{2}\right) \quad X=C H$<smiles>Nc1ncnc2c1ncn2CC(O)CO</smiles>

(R)-DHPA (S)-DHPA<smiles>COC1C=CC2C1C=NC21CC(N)=NC=N1</smiles>

K $\$ 605$<smiles>Nc1nccc2c1ncn2C1CCC(O)C1O</smiles>

DHCaA $\quad \mathrm{X}=\mathrm{N}$ c3DHCaA $\mathrm{X}=\mathrm{CH}$<smiles>Nc1nccc2c1ncn2C1CC2C(O)C1C2O</smiles>

C.C3Ado

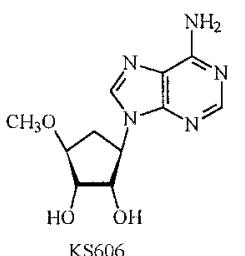

$\mathrm{KS} 606$<smiles>Nc1ncnc2c1ncn2C1CC(O)C(O)C1O</smiles>

5'-noraristeromycin<smiles>[X]c1cnc(N)c2ncn(C3OC(CO)C(O)C3O)c12</smiles>

NKO-6-16-3 $\quad X=F$ NOM-14-6-1 $\mathrm{X}=\mathrm{Cl}$<smiles>Nc1ncnc2c1ccn2C1CCC(O)C1O</smiles><smiles>[R]C(O)C1=CC(n2cnc3c(N)ncnc32)C(O)C1O</smiles>

6'-(R)-methylneplanocin A $\mathrm{R}: \mathrm{CH}_{3}$ $6^{\prime}$-(R)-ethylneplanocin A $\quad \mathrm{R}: \mathrm{CH}_{2}-\mathrm{CH}_{3}$ 6'-(R)-ethenylneplanocin A $\mathrm{R}: \mathrm{CH}=\mathrm{CH}_{2}$ 6'-(R)-ethynylneplatnocin A $\quad \mathrm{R}: \mathrm{C}=\mathrm{CH}$ 6'-(S)-methylneplanocin A $\quad \mathrm{R}: \mathrm{CH}_{3}$

6'-(S)-etlyyineplarusin A $\mathrm{R}: \mathrm{CH}_{2}-\mathrm{CH}_{3}$

6'-(S)-etlenylne? lanocin $\mathrm{A} \quad \mathrm{R}: \mathrm{CH}=\mathrm{CH}_{2}$

Fig. 1. Formulae of the adenosine analogues that were evaluated as inhibitors of AdoHcy hydrolase, HIV-1 replication, and Tat-transactivation.

AdoHcy hydrolase activity was measured in the direction of AdoHcy synthesis using $8-\left[{ }^{14} \mathrm{C}\right]$ Ado (Amersham, Buckinghamshire, England) and $2 \mathrm{~mm}$ DL-Hcy as substrates, as described previously (7). The kinetic properties of the murine AdoHcy hydrolase enzyme differ only slightly from those of human AdoHcy hydrolase. For the human enzyme, $K_{m}$ values of $\approx 1 \mu \mathrm{M}$ have been reported adenosine, whereas the $K_{m}$ values for AdoHcy vary from 0.75 to $15 \mu \mathrm{M}$ (25). The $K_{m}$ values of purified enzyme from murine L929 cells are $0.5 \mu \mathrm{M}$ for adenosine and $4.8 \mu \mathrm{M}$ for AdoHcy.

Inhibition of HIV-1 replication in MT-4 cells. In MT-4 cells, the anti-HIV-1 activities of the test compounds were determined by $\tilde{\sim}$ measuring virus-induced cytopathogenicity (26). Briefly, MT-4 cells $\vec{N}$ were suspended at $3 \times 10^{5}$ cells $/ \mathrm{ml}$ and infected with HIV at 100 times the $50 \%$ cell culture infective dose/ml. Immediately after infection, $100 \mu \mathrm{l}$ of the cell suspension was added to each well of flat-bottom 96-well microtiter trays containing various concentrations of the test compound. After 5 days of incubation at $37^{\circ}$, the number of viable cells was determined according to the 3-(4,5-dimethylthiazol-2-yl)-2,5-diphenyltetrazolium bromide method as described previously (27).

Inhibition of HIV-1 p24 production in PBLs. The inhibitory effects of the compounds on HIV-1 strain $\mathrm{III}_{\mathrm{B}}$ replication in PBLs were monitored 7 days after infection by quantification of HIV-1 p24 core antigen using an enzyme-linked immunosorbent assay (DuPont, 
Wilmington, DE). These experiments were performed according to the ACTG protocol.

Inhibition of HIV-1 replication in persistently HIV-1 in-

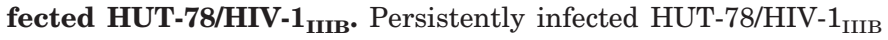
cells were cultured for 3 days in the presence of various concentrations of test compounds. Anti-HIV-1 activity was determined by monitoring viral p24 antigen expression by enzyme-linked immunosorbent assay (DuPont). The supernatant of the cells incubated in the presence of various concentrations of compound was used to determine virus yield according to the Reed and Muench end point dilution assay (28).

Inhibition of HIV-1 replication in macrophages. Primary macrophages (obtained from blood monocytes) were infected with 300 tissue culture infectious doses of monocytotropic strain HIV$1_{\mathrm{Ba}-\mathrm{L}}$ and maintained in culture until day 10 , when chronic infection is usually established (29). At this time, macrophages were treated with different concentrations of $\mathrm{DHCaA}$ and $\mathrm{c}^{3} \mathrm{DHCaA}$. Drugs were maintained in culture throughout the whole experiment. Inhibition of virus replication was assessed in the supernatants of macrophages at different time points by a commercially available immunoassay able to detect the presence of HIV p24 (Abbott Laboratories, Pomezia, Italy). Toxicity was assessed by trypan blue exclusion method on macrophages detached from wells 5-11 days after the beginning of the treatment and compared with the number and viability of macrophages found in control untreated (but infected) cells. Details about the experimental procedure are given elsewhere $(29,30)$.

Inhibition of HIV-1 replication in $\mathbf{P} 4$ cells. In $\mathrm{P} 4$ cells (HeLaCD4-LTR-LacZ), the anti-HIV-1 activity of the test compounds was determined by measuring virus-induced $\beta$-Gal expression and p24 antigen production. At day -1 , the cells were plated in microtiter plates at $2 \times 10^{4}$ cells/well and incubated overnight at $37^{\circ}$ with $5 \%$ $\mathrm{CO}_{2}$. At day 0 , the medium was removed by gentle aspiration, and cells were infected with an excess of HIV-1 $1_{\text {IIIB }}$ for $\sim 1 \mathrm{hr}$ (multiplicity of infection >1). After infection, various concentrations of test compounds were added to the infected cells. Two days after infection virus replication was monitored by measuring p24 antigen production and by measuring $\beta$-Gal expression in the cell extracts. $\beta$-Gal activity and p24 antigen were measured with the same assays as described for the transactivation assay (24) and the other replication assay, respectively. The $\mathrm{IC}_{50}$ value was calculated as being the inhibitor concentration that reduces $\beta$-Gal expression or the p24 production by $50 \%$.

HIV-1 RT assay. The enzymatic activity of recombinant HIV-1 RT was tested using poly(C)/oligo(dG) as template/primer and ${ }^{3} \mathrm{H}$ labeled dGTP as substrate in an RNA-dependent DNA-polymerase reaction. RT assays were performed in a reaction buffer containing $50 \mathrm{~mm}$ Tris $\cdot \mathrm{HCl}, \mathrm{pH} 8.1,2 \mathrm{~mm}$ dithiothreitol, $10 \mathrm{~mm} \mathrm{MgCl}_{2}, 0.01 \%$ Triton X-100, $2.5 \mu \mathrm{M}\left[8-{ }^{3} \mathrm{H}\right] \mathrm{dGTP}, 65 \mu \mathrm{g} / \mathrm{ml}$ poly(C)/oligo(dG), $2 \mathrm{nM}$ concentrations of RT enzyme preparations, and appropriate concentrations of the compounds, as described previously (31). The $\mathrm{IC}_{50}$ value was calculated as being the concentration of inhibitor that reduces the RT activity by $50 \%$.

Cellular toxicity. Cellular toxicity of the compounds was measured by on the basis of trypan blue exclusion, the 3-(4,5-dimethylthiazol-2-yl)-2,5-diphenyltetrazolium bromide method (27), or total protein content in the cell extracts. The latter was determined according to the Bradford method (BioRad).

\section{Results}

Inhibition of HIV-1 transactivation. The $\beta$-Gal transactivation assay allowed us to quantify HIV-1 LTR transactivation by Tat in Hela-tat-III cells after transient transfection with pHIVLacZ. Tat-independent transactivation of the HIV-1 LTR by TNF- $\alpha$ was also measured in pHIVLacZ-transfected P4 cells. After Tat-dependent or -independent transactivation of the HIV-1 LTR, the expression of $\beta$-Gal activity was increased up to 50-fold; therefore, these assays provide a sensitive way to study HIV-1 LTR activity.

The compound Ro5-3335, previously reported to be a transactivation inhibitor, inhibited the Tat-dependent expression of the $L a c Z$ gene at a $\mathrm{IC}_{50}$ value of $0.44 \mu \mathrm{M}$, a result that is compatible with previous reports $(18,19)$. All the AdoHcy hydrolase inhibitors tested were able to inhibit the Tat-dependent $\beta$-Gal expression (Table 1). The most potent inhibitors were $\mathrm{DHCaA}\left(\mathrm{IC}_{50}=0.21 \mu \mathrm{M}\right), \mathrm{NPA}\left(\mathrm{IC}_{50}=0.23\right.$ $\mu \mathrm{M}), 5^{\prime}$-noraristeromycin $\left(\mathrm{IC}_{50}=0.24 \mu \mathrm{M}\right), \mathrm{c}^{3} \mathrm{DHCaA}\left(\mathrm{IC}_{50}=\right.$ $0.26 \mu \mathrm{M})$, and $\mathrm{c}^{3} \mathrm{NPA}\left(\mathrm{IC}_{50}=0.30 \mu \mathrm{M}\right)$. The $(R)$-isomer of $6^{\prime}$-methyl-NPA $\left(\mathrm{IC}_{50}=0.32 \mu \mathrm{M}\right)$ was $>110$-fold more potent than the $(S)$-isomer $\left(\mathrm{IC}_{50}>36 \mu \mathrm{M}\right)$. The same differential inhibitory activity was observed for $(R)$ - and $(S)$-isomers of 6 '-ethynyl-NPA and 6'-ethenyl-NPA. Adenosine analogues that were inactive as AdoHcy hydrolase inhibitors were also inactive against transactivation of the HIV-1 LTR. Similar $\mathrm{IC}_{50}$ values were obtained for the inhibition of the HIV-1 LTR activation by TNF- $\alpha$ (Table 1 ). None of the compounds were able to inhibit the $\beta$-Gal expression in cells transiently transfected with $\mathrm{pCMV} \beta$ DNA, a plasmid containing the Tatindependent cytomegalovirus promoter driving the LacZ gene.

Inhibition of HIV-1 replication. In the MT-4/3-(4,5-dimethylthiazol-2-yl)-2,5-diphenyltetrazolium bromide HIV-1 replication assay, the anti-HIV-1 activities of $c^{3} \mathrm{NPA}$ and C-c ${ }^{3}$ Ado were determined by measuring the inhibition of $O$ virus-induced cytopathogenicity (26). At subtoxic concentra- 으 tions, no inhibition of HIV-induced cytopathogenicity could be found in MT-4 cells $\left(\mathrm{CC}_{50}: \mathrm{c}^{3} \mathrm{NPA}, 0.072 \mu \mathrm{M}\right.$; C-c ${ }^{3} \mathrm{Ado}, 7.1$ $\mu \mathrm{M})$.

Inhibition of replication of HIV-1 sured by quantifying the p24 antigen production in the presence of varying concentrations of test compound. The $\mathrm{IC}_{50}$ value of DHCaA for HIV-1 replication was $0.052 \mu \mathrm{M}$; this was $\sim 2$-fold higher than the $\mathrm{CC}_{50}$ value $(0.023 \mu \mathrm{M})$.

When evaluated for their inhibitory effects on HIV-1 replication in persistently infected HUT-78/HIV-1 $1_{\text {IUB }}$ cells, $c^{3} \mathrm{NPA}$ and $\mathrm{C}-\mathrm{c}^{3} \mathrm{Ado}$ at subtoxic concentrations did not reduce HIV-1 progeny yield, as measured by quantification of the p24 core antigen $\left(\mathrm{CC}_{50}: \mathrm{c}^{3} \mathrm{NPA}, 0.38 \mu \mathrm{M} ; \mathrm{C}^{\mathrm{c}} \mathrm{c}^{3} \mathrm{Ado}, 15 \mu \mathrm{M}\right)$.

The activity of DHCaA and $c^{3} \mathrm{DHCaA}$ was then assessed in chronically infected primary macrophages. We found preliminarily that the $\mathrm{CC}_{50}$ value of either compound was in the range of $4.6 \mu \mathrm{M}$. No detectable activity, at least in term of production of p24 antigen assessed in the supernatants at different time points (i.e., day 1, 3, or 5 after treatment with antiviral drugs), was found in three consecutive experiments. $)$ Approximately 90\% inhibition of virus production was $\vec{\sigma}$ achieved with $5 \mathrm{~mm} 282-870$, a protease inhibitor provided of $\tilde{\sim}$ potent activity both in acutely and chronically infected cells $\overrightarrow{\mathrm{N}}$ (32).

Inhibition of HIV-1 replication in P4 cells was measured by quantifying the transactivation of the HIV-1 LTR by viral Tat using the $L a c Z$ reporter gene or quantifying p24 antigen production in the culture medium. P4 cells, HeLa-CD4 cells with stably integrated LTR-LacZ, were infected with HIV$1_{\text {IIIB }}$ and treated with the compounds. Dextran sulfate $\left(\mathrm{IC}_{50}\right.$ $=0.007 \mu \mathrm{M}), 3^{\prime}$-azido-3'-deoxythymidine $\left(\mathrm{IC}_{50}=3.4 \times 10^{-4}\right.$ $\mu \mathrm{M})$, and saquinavir $\left(\mathrm{IC}_{50}=0.82 \mu \mathrm{M}\right)$, known as HIV-1 replication inhibitors, all inhibited the $L a c Z$ expression and p24 production in infected $\mathrm{P} 4$ cells in a dose-dependent manner. 
TABLE 1

Inhibitory effects of Ro5-3335 and AdoHcy hydrolase inhibitors on transactivation of the HIV-1 LTR

\begin{tabular}{|c|c|c|c|c|c|}
\hline & $\begin{array}{l}\text { Inhibition of } \mathrm{AdoH} \text { cy } \\
\text { hydrolase, } \mathrm{IC}_{50}{ }^{a}\end{array}$ & $\begin{array}{c}\text { Inhibition of Tat- } \\
\text { dependent } \\
\text { transactivation, } \mathrm{IC}_{50}{ }^{b}\end{array}$ & $\begin{array}{l}\text { Inhibition of TNF- } \alpha \\
\text { induced transactivation, } \\
\qquad \mathrm{IC}_{50}{ }^{c}\end{array}$ & $\begin{array}{l}\text { Inhibition of Tat-independent } \\
\text { cytomegalovirus promoter, } I_{50}{ }^{d}\end{array}$ & $\begin{array}{l}\text { Toxicity, } \\
\mathrm{CC}_{50} e\end{array}$ \\
\hline & \multicolumn{5}{|c|}{$\mu M$} \\
\hline Ro5-3335 & 510 & $0.44 \pm 0.17$ & $0.53 \pm 0.40$ & $>44$ & $>44$ \\
\hline NPA & 0.015 & $0.23 \pm 0.03$ & $0.90 \pm 0.72$ & $>38$ & $>38$ \\
\hline$c^{3} N P A$ & 0.031 & $0.30 \pm 0.15$ & $0.11 \pm 0.10$ & $>76$ & $>76$ \\
\hline $\mathrm{DHCaA}$ & 0.37 & $0.21 \pm 0.01$ & $0.25 \pm 0.04$ & $>43$ & $>43$ \\
\hline $\mathrm{c}^{3} \mathrm{DHCaA}$ & 0.21 & $0.26 \pm 0.01$ & $0.25 \pm 0.04$ & $>43$ & $>43$ \\
\hline C-c ${ }^{3}$ Ado & 0.018 & $1.10 \pm 0.75$ & $1.10 \pm 1.20$ & $>150$ & $>150$ \\
\hline 5'-Noraristeromycin & 0.042 & $0.24 \pm 0.04$ & $0.47 \pm 0.35$ & $>40$ & $>40$ \\
\hline $6^{\prime}-(R)$-methyl-NPA & 0.1 & $0.32 \pm 0.14$ & $0.36 \pm 0.21$ & $>36$ & $>36$ \\
\hline $6^{\prime}-(S)$-methyl-NPA & 256 & $>36$ & $>36$ & $>36$ & $>36$ \\
\hline (S)-DHPA & 5.35 & $38.00 \pm 4.80$ & $>48$ & $>48$ & $>48$ \\
\hline$(R)$-DHPA & 81.5 & $>49$ & & $>48$ & $>48$ \\
\hline $\mathrm{c}^{7} \mathrm{DHCaA}$ & $>100$ & $>43$ & & $>43$ & $>43$ \\
\hline KS605 & 393 & $>258$ & & $>258$ & $>258$ \\
\hline KS606 & 36 & $182.00 \pm 60.00$ & & $>225$ & $>225$ \\
\hline NOM-14-6-1 & 21.7 & $7.00 \pm 1.50$ & & $>188$ & $>188$ \\
\hline NKO-6-16-3 & 13 & 31.50 & & $>211$ & $>211$ \\
\hline $6^{\prime}-(R)$-Ethynyl-NPA & 0.25 & $0.90 \pm 0.62$ & & $>209$ & $>209$ \\
\hline 6'-(S)-Ethynyl-NPA & 16 & $>209$ & & $>209$ & $>209$ \\
\hline $6^{\prime}-(R)$-Ethenyl-NPA & 2.15 & $0.96 \pm 0.72$ & & $>208$ & $>208$ \\
\hline 6'-(S)-Ethenyl-NPA & 287 & $>207$ & & $>208$ & $>208$ \\
\hline $6^{\prime}-(R)$-Ethyl-NPA & 40 & $>206$ & & $>206$ & $>206$ \\
\hline 6'-(S)-Ethyl-NPA & $>500$ & $>70$ & & $>206$ & $>206$ \\
\hline
\end{tabular}

a Concentration of the inhibitor required for $50 \%$ inhibition of AdoHcy hydrolase activity.

${ }^{b}$ Concentration of the inhibitor required for $50 \%$ inhibition of $\beta$-Gal expression driven by the HIV- 1 LTR in transfected HeLa-tat-III cells.

${ }^{c}$ Concentration of the inhibitor required for $50 \%$ inhibition of $\beta$-Gal expression induced by TNF- $\alpha$ in pHIV LacZ-transfected cells.

${ }^{a}$ Concentration of the inhibitor required for $50 \%$ inhibition of $\beta$-Gal expression driven by the CMV promoter in transfected HeLa-tat-III cells.

${ }^{e}$ Concentration of the inhibitor required for $50 \%$ inhibition of total protein expression in cell culture.

Data represent mean values of two to four separate experiments, each performed in triplicate.

Ro5-3335, known as an HIV transactivation inhibitor (18, 19), inhibited the HIV-1-induced expression of the LacZ gene and $\mathrm{p} 24$ production with an $\mathrm{IC}_{50}$ value of $0.1 \mu \mathrm{M}$. The $\mathrm{IC}_{50}$ values obtained for the adenosine analogues are given in Table 2. All the AdoHcy hydrolase inhibitors tested were able to inhibit the virus induced $\beta$-Gal expression and p24 production in $\mathrm{P} 4$ cells. The most potent inhibitors were, again, $\mathrm{c}^{3} \mathrm{DHCaA}\left(\mathrm{IC}_{50}=0.29 \mu \mathrm{M}\right), \mathrm{c}^{3} \mathrm{NPA}\left(\mathrm{IC}_{50}=0.41 \mu \mathrm{M}\right), \mathrm{DHCaA}$ $\left(\mathrm{IC}_{50}=1.3 \mu \mathrm{M}\right)$, and NPA $\left(\mathrm{IC}_{50}=1.9 \mu \mathrm{M}\right)$. The same differential activity of the $(R)$-and $(S)$-isomers as observed in the transactivation assay was again seen in the replication assay. For example, the $(R)$-isomer of $6^{\prime}$-methyl-NPA $\left(\mathrm{IC}_{50}=\right.$ $3.5 \mu \mathrm{M})$ was $>10$-fold more potent than the $(S)$-isomer $\left(\mathrm{IC}_{50}=\right.$ $>36 \mu \mathrm{M})$. Those adenosine analogues that were inactive as AdoHcy hydrolase inhibitors were also inactive for HIV-1 replication in P4 cells (Tables 1 and 2). With the exception of $\mathrm{NPA}\left(\mathrm{CC}_{50}=30 \mu \mathrm{M}\right), \mathrm{c}^{3} \mathrm{NPA}\left(\mathrm{CC}_{50}=76 \mu \mathrm{M}\right), \mathrm{DHCaA}\left(\mathrm{CC}_{50}\right.$ $=55 \mu \mathrm{M})$, and $\mathrm{c}^{3} \mathrm{DHCaA}\left(\mathrm{CC}_{50}=37 \mu \mathrm{M}\right)$, most of the test compounds were not toxic to the cells at concentrations tested as measured by total protein content according to the Bradford method (Table 2).

Inhibition of HIV-1 RT. The inhibitory effects of DHCaA and $c^{3} \mathrm{DHCaA}$ on the RT were evaluated using poly $(\mathrm{C}) / \mathrm{oli}-$ go $(\mathrm{dG})$ as template/primer. Neither of the test compounds showed any activity against HIV-1 RT.

Correlation among inhibition of AdoHcy hydrolase activity, HIV-1 Tat-transactivation, and HIV-1 replication. The $\mathrm{IC}_{50}$ values of the compounds for AdoHcy hydrolase were compared with their $\mathrm{IC}_{50}$ values on Tat-transactivation and HIV-1 replication in P4 cells. There was a close correlation among the inhibitory effects of the compounds on AdoHcy hydrolase, Tat-transactivation, and HIV-1 replica- tion in $\mathrm{P} 4$ cells. When $\mathrm{IC}_{50}$ values of the compounds for AdoHcy hydrolase were plotted on a log-log scale as a function of their $\mathrm{IC}_{50}$ values for Tat-transactivation (Fig. 2), linear regression showed a nice linear correlation (linear $r=$

TABLE 2

Inhibitory effects of control compounds DS, AZT, Ro5-3335, and Saquinavir and AdoHcy hydrolase inhibitors on HIV-1 replication

\begin{tabular}{|c|c|c|}
\hline & $\begin{array}{l}\text { Inhibition of virus-induced } \operatorname{LacZ} \\
\text { expression, } \mathrm{IC}_{50}{ }^{a}\end{array}$ & Toxicity, $\mathrm{CC}_{50}{ }^{b}$ \\
\hline & \multicolumn{2}{|l|}{$\mu M$} \\
\hline DS 5000 & $0.007 \pm 0.001$ & $>2$ \\
\hline $\mathrm{AZT}$ & $0.00034 \pm 0.000022$ & $>0.04$ \\
\hline Ro5-3335 & $0.1 \pm 0.05$ & $3.36 \pm 2.58$ \\
\hline Saquinavir & $0.8 \pm 0.5$ & $>15$ \\
\hline NPA & $1.9 \pm 2.7$ & $30 \pm 31$ \\
\hline$c^{3} N P A$ & $0.41 \pm 1.5$ & $76 \pm 21$ \\
\hline $\mathrm{DHCaA}$ & $1.3 \pm 1$ & 55 \\
\hline$c^{3} \mathrm{DHCaA}$ & $0.29 \pm 0.0042$ & $37 \pm 25$ \\
\hline C-c ${ }^{3}$ Ado & $7.4 \pm 5$ & $>37$ \\
\hline 6'-(R)-Methyl-NPA & $3.5 \pm 0.5$ & $>36$ \\
\hline 6'-(S)-Methyl-NPA & $>36$ & $>36$ \\
\hline (S)-DHPA & $248 \pm 189$ & $>191$ \\
\hline$c^{7} \mathrm{DHCaA}$ & 51 & $>42$ \\
\hline $6^{\prime}-(R)$-Ethynyl-NPA & 38 & $>69$ \\
\hline 6'-(S)-Ethynyl-NPA & $>104$ & $>104$ \\
\hline 6'-(R)-Ethenyl-NPA & $6.16 \pm 3$ & $>69$ \\
\hline 6'-(S)-Ethenyl-NPA & $57 \pm 52$ & $>138$ \\
\hline 6'-(R)-Ethyl-NPA & $4.6 \pm 0.34$ & $>68$ \\
\hline 6'-(S)-Ethyl-NPA & $67 \pm 3.7$ & $>68$ \\
\hline
\end{tabular}

${ }^{a}$ Concentration of the inhibitor required for $50 \%$ inhibition of $\beta$-Gal expression driven by the HIV- 1 LTR in HIV- 1 -infected CD4 ${ }^{+}$HeLa cells.

${ }^{b}$ Concentration of the inhibitor required for $50 \%$ inhibition of total protein expression in cell culture.

Data represent mean values of two to four separate experiments, each performed in triplicate. 


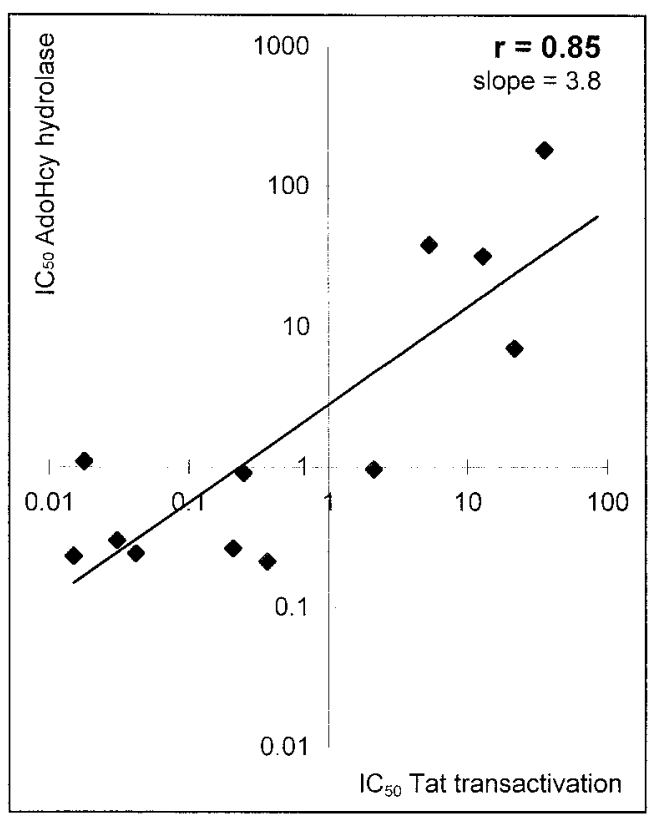

Fig. 2. Linear regression for $I C_{50}$ values of NPA, $c^{3} N P A, D H C a A$, $c^{3} \mathrm{DHCaA}, \mathrm{C}-\mathrm{c}^{3} \mathrm{Ado}, 5^{\prime}$-noraristeromycin, KS606, NOM-14-6-1, NKO6-16-3, (S)-DHPA, 6'-(R)-methyl-NPA, $6^{\prime}-(R)$-ethenyl-NPA, and 6'-(R)ethynyl-NPA for their inhibition of AdoHcy hydrolase as a function of their $\mathrm{IC}_{50}$ values for Tat-transactivation of HIV-1.

0.85 with a slope of 3.8) between the inhibitory effects on AdoHcy hydrolase and Tat-transactivation. The correlation coefficient between the inhibitory effects on virus replication in $\mathrm{P} 4$ cells and Tat-transactivation was 0.99 with a slope of 0.15 (Fig. 3). When the $\mathrm{IC}_{50}$ values of the compounds for HIV-1 replication in $\mathrm{P} 4$ cells were plotted as a function of their $\mathrm{IC}_{50}$ values for AdoHcy hydrolase (Fig. 4), linear regression again showed a close linear correlation (linear $r=0.91$

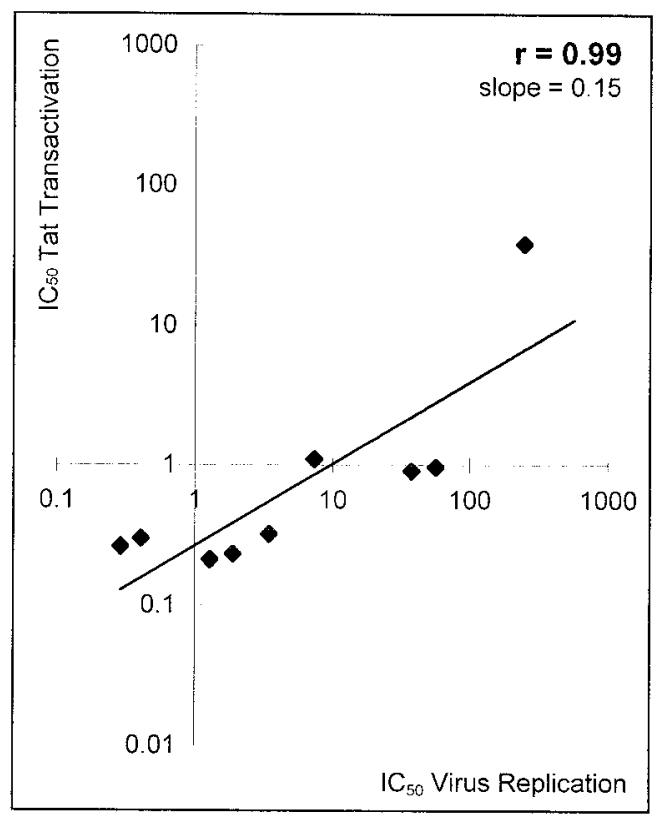

Fig. 3. Linear regression for $I C_{50}$ values of NPA, $c^{3} \mathrm{NPA}, \mathrm{DHCaA}$, $\mathrm{C}^{3} \mathrm{DHCaA}, \mathrm{C}-\mathrm{c}^{3} \mathrm{Ado},(S)$-DHPA, $6^{\prime}-(R)$-methyl-NPA, $6^{\prime}$ - $(R)$-ethenyl-NPA, and $6^{\prime}-(R)$-ethynyl-NPA for their $I_{50}$ values of HIV-1 Tat-transactivation inhibition as function of their inhibition of HIV-1 replication in P4 cells.

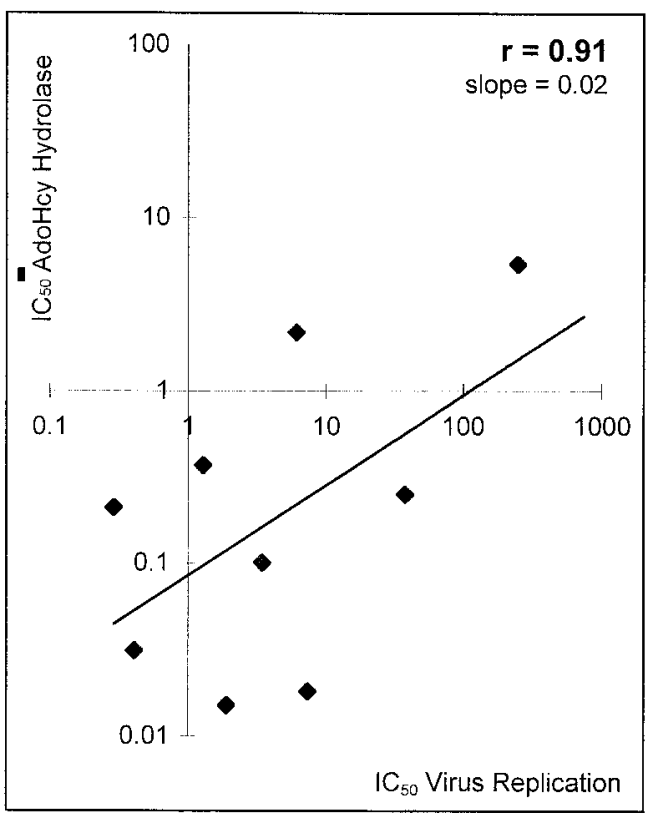

Fig. 4. Linear regression for $I C_{50}$ values of NPA, $c^{3} N P A, D H C a A$, $\mathrm{C}^{3} \mathrm{DHCaA}, \mathrm{C}-\mathrm{c}^{3} \mathrm{Ado},(\mathrm{S})$-DHPA, $6^{\prime}-(R)$-methyl-NPA, 6'-(R)-ethenyl-NPA, and $6^{\prime}-(R)$-ethynyl-NPA for their inhibition of HIV-1 replication in P4 cells as function of their $\mathrm{IC}_{50}$ values for AdoHcy hydrolase inhibition.

with a slope of 0.02 ) between the inhibitory effects on virus replication and AdoHcy hydrolase.

\section{Discussion}

The HIV Tat protein stimulates transcriptional initiation and elongation through interaction with a cis-acting element located within the HIV LTR, termed the TAR (13-16). The molecular mechanism by which Tat functions is not yet completely understood, but several lines of evidence suggest that transactivation of the Tat protein is mediated by cellular factors: Tat stimulates transactivation in a cell-dependent manner (33), and cellular proteins that bind TAR in vitro have been described (for reviews, see Refs. 34 and 35). The HIV-1 LTR can also be trans-activated by lymphocyte-activating factors such as TNF- $\alpha$.

It has been clearly established that adenosine analogues are inhibitory to AdoHcy hydrolase $(3,36,37)$. More recently, Mayers et al. (10) reported the activity of 3-deazaadenosine analogues against HIV-1. They postulated that the $5^{\prime}-O$ triphosphate of 3-deazaadenosine $(38,39)$ may act as an inhibitor of viral DNA or RNA synthesis (10). However, the $\stackrel{3}{3}$ investigators did not measure the inhibitory activity of the $\vec{\sigma}$ 5 - $O$-triphosphate derivatives of 3-deazaadenosine analogues $\tilde{a}$ against HIV-1 RT in a cell-free system to confirm this hy- $\vec{N}$ pothesis. Moreover, we believe that it is rather unlikely that ribonucleotides are efficiently recognized by DNA polymerases, such as HIV-1 RT, as a substrate or an inhibitor of the enzyme reaction. In fact, all compounds we tested contain both 2 '- and 3'-hydroxyl groups (Fig. 1). Moreover, DHCaA and $c^{3} \mathrm{DHCaA}$ cannot be converted in the cell to a triphosphate form at the $5^{\prime}$ position (see Fig. 1) and therefore cannot inhibit the HIV-1 RT reaction as chain terminator. Furthermore, in additional experiments, it was determined that DH$\mathrm{CaA}$ and $c^{3} \mathrm{DHCaA}$ did not have a direct inhibitory effect on the HIV-1 RT reaction. 
Here, we suggest that these adenosine analogues, described as HIV-1 inhibitors by Mayers et al. (10), most probably act through their inhibition of AdoHcy hydrolase. We demonstrate that adenosine analogues that are able to inhibit AdoHcy hydrolase have potent inhibitory effect on the Tat-dependent and TNF- $\alpha$-induced transactivation of a reporter gene driven by the HIV-1 LTR. The most active agents that emerged were $\mathrm{DHCaA}, \mathrm{NPA}, 5^{\prime}$-noraristeromycin, $\mathrm{c}^{3} \mathrm{DHCaA}$, and 3-deazaneplanocin $\mathrm{A}$. The fact that similar $\mathrm{IC}_{50}$ values as obtained for the Tat-dependent inhibition were obtained for the Tat-independent inhibition of LTR transactivation means that these adenosine analogues interfere with the HIV-1 LTR transactivation in general through a Tat-independent mechanism. The compounds were tested in different host cells, but no anti-HIV activity could be observed in MT-4 cells or PBLs at subtoxic concentrations. Moreover, in chronically infected macrophages, we found no detectable activity. This was not surprising, however, because previous data, confirmed in this set of experiments, show that inhibition of virus production in chronically infected macrophages can be achieved only with protease inhibitors and at concentrations $\geq 10-50$-fold higher than those active in chronically infected lymphocytes and $\sim 100-$ 1000 -fold greater than those active after de novo infection of lymphocytes. Indeed, Ro5-3335, known as an HIV transactivation inhibitor, is also completely inactive in this system. When tested in $\mathrm{CD}^{+}$HeLa cells, all AdoHcy hydrolase inhibitors inhibited HIV-1 $1_{\text {IIIB }}$ replication at subtoxic concentrations (Table 2). Of the two diastereoisomers of $6^{\prime}$-methylNPA, the $(R)$-isomer proved to be much more active than the $(S)$-isomer. This differential inhibitory activity of the two diastereoisomers was reflected in their inhibitory effect on HIV-1 LTR transactivation, AdoHcy hydrolase activity, and HIV-1 replication in P4 cells (Tables 1 and 2).

AdoHcy hydrolase is functionally linked to AdoMet-dependent methyltransferases (4). When serving as the methyl donor for methyltransferase reactions, AdoMet generates AdoHcy, which is not only a product but also an inhibitor of the methyltransferase reaction. To avoid this inhibitory effect and allow the methyltransferases to proceed, AdoHcy must be removed by AdoHcy hydrolase. The fact that AdoHcy hydrolase inhibitors exert a potent inhibition of Tat-mediated and TNF- $\alpha$-induced transactivation of the LTR points to the participation of the AdoMet-dependent methyltransferase/AdoHcy hydrolase system in the transactivation process.

We demonstrated a close correlation among the inhibitory effect on AdoHcy hydrolase, HIV replication, and transactivation activity for a wide range of adenosine analogues (Figs. 2-4). A similar correlation was found earlier between their inhibitory effects on AdoHcy hydrolase and their activity against a number of viruses (vaccinia virus, vesicular stomatitis virus, and cytomegalovirus) (6, 7). The strong correlation between AdoHcy hydrolase inhibition and anti-HIV-1 transactivation suggests that the AdoHcy hydrolase inhibitors may interfere with the HIV transactivation process via inhibition of AdoHcy hydrolase (Fig. 2). Furthermore, the close correlation between the inhibition of virus replication and inhibition of Tat-transactivation suggests that the antiHIV-1 activity of the AdoHcy hydrolase inhibitors is due to inhibition of HIV-1 Tat-transactivation (Fig. 3). The AdoHcy hydrolase inhibitors may inhibit HIV-1 Tat-transactivation through interference with the HIV-1 transcription or with the 5 -capping of the HIV-1 mRNA. The latter is required for the folding of the TAR stem structure, which in turn is required for the effective activation of the LTR. In any case, the mode of action of the AdoHcy hydrolase inhibitors seems to be specifically related to the HIV-1 LTR transactivation because the AdoHcy hydrolase inhibitors tested did not have any effect on the expression of the $L a c Z$ gene driven by a Tat-independent cytomegalovirus promoter.

We suggest that the adenosine analogues exert their antiHIV-1 activity through inhibition of Tat-transactivation via inhibition of AdoHcy hydrolase. The exact molecular mechanism by which the AdoHcy hydrolase inhibitors interfere with the Tat-transactivation of HIV-1 remains to be elucidated.

Due to the high toxicity in PBLs and T cell lines such as MT-4 and HUT-78 cells, these adenosine analogues might not be immediate candidates for clinical trials. However, they are helpful in improving our understanding of the HIV LTR transactivation mechanism, which opens perspectives for future drug design aimed at interfering with the HIV transactivation.

\section{Acknowledgments}

We are grateful to Dr. S. Shuto, Dr. A. Matsuda, and Dr. S. W. Schneller for kindly providing their test compounds. We thank Cindy Heens and Kristien Erven for excellent technical assistance and Jan Balzarini for stimulating discussions.

\section{References}

1. de la Haba, G., and G. L Cantoni. The enzymatic synthesis of Sadenosylhomocysteine from adenosine and homocysteine. J. Biol. Chem. 234:603-608 (1959)

2. Borchardt, R. T. S-Adenosyl-L-methionine-dependent macromolecule methyltransferases: potential targets for design of chemotherapeutic agents. J. Med. Chem. 23:347-357 (1980).

3. De Clercq, E. S-Adenosylhomocysteine hydrolase inhibitors as broadspectrum antiviral agents. Biochem. Pharmacol. 36:2567-2575 (1987).

4. De Clercq, E., M. Cools, J. Balzarini, V. E. Marquez, D. R. Borcherding, R. T. Borchardt, J. C. Drach, S. Kitaoka, and T. Konno. Broad-spectrum antiviral activities of neplanocin A, 3-deazaneplanocin A, and their 5'-nor derivatives. Antimicrob. Agents Chemother. 33:1291-1297 (1989).

5. De Clercq, E. Antiviral activity spectrum and target of action of different classes of nucleoside analogues. Nucleosides Nucleotides 13:1271-1295 (1994).

6. Snoeck, R., G. Andrei, J. Neyts, D. Schols, M. Cools, J. Balzarini, and E. De Clercq. Inhibitory activity of S-adenosylhomocysteine hydrolase inhibitors against human cytomegalovirus replication. Antiviral Res. 21:197-216 (1993).

7. Cools, M., and E. De Clercq. Correlation between the antiviral activity of acyclic and carbocyclic adenosine analogues and their inhibitory effect on L929 cell S-adenosylhomocysteine hydrolase. Biochem. Pharmacol. 38: 1061-1067 (1989).

8. Franchetti, P., L. Cappellacci, G. Cristalli, M. Grifantini, A. Pani, P. La Colle, and G. Nocentini. Synthesis and evaluation of anti-HIV-1 and antitumor activity of $2^{\prime}, 3^{\prime}$-didehydro-2', $3^{\prime}$-dideoxy-3-deazaadenosine, $2^{\prime}, 3^{\prime}$ dideoxy-3-deazaadenosine and some $2^{\prime}, 3^{\prime}$-dideoxy-3-deazaadenosine $5^{\prime}$ dialkyl phosphates. Nucleosides Nucleotides 10:1551-1562 (1991).

9. Flexner, C. W., J. E. Hildreth, R. W. Kuncl, and D. B. Drachman. 3- $\vec{N}$ Deazaadenosine and inhibition of HIV. Lancet 339:438 (1992).

10. Mayers, D. L., J. A. Mikovits, B. Joshi, I. K. Hewlett, J. S. Estrada, A. D. Wolfe, G. E. Garcia, B. P. Doctor, D. S. Burke, R. K. Gordon, J. R. Lane, and $\mathrm{P}$. Chiang. Anti-human immunodeficiency virus 1 (HIV-1) activities of 3-deazaadenosine analogues: increased potency against 3 '-azido-3'deoxythymidine-resistant HIV-1 strains. Proc. Natl. Acad. Sci. USA 92: 215-219 (1995).

11. Arya, S. K., C. Guo, S. F. Josephs, and F. Wong-Staal. Trans-activator gene of human T-lymphotropic virus type III (HTLV-III). Science (Washington D. C.) 229:69-73 (1985).

12. Berkhout, B., R. H. Silverman, and K. T. Jeang. Tat transactivates the immunodeficiency virus through a nascent RNA target. Cell 59:273-282 (1989).

13. Feng, S., and E. C. Holland. HIV-1 Tat trans-activation requires the loop sequence within TAR. Nature (Lond.) 334:165-167 (1988). 
14. Garcia, J. A., D. Harrich, E. Soultanakis, F. Wu, H. Mitsuya, and R. B. Gaynor. Human immunodeficiency virus type 1 LTR TAT and TAR region sequences required for transcription regulation. $E M B O \mathrm{~J}$. 8:765-778 (1989).

15. Hauber, J., and B. R. Cullen. Mutational analysis of the trans-activationresponsive region of the human immunodeficiency virus type 1 long terminal repeat. J. Virol. 62:673-679 (1988).

16. Rosen, C. A., J. G. Sodroski, and W. A. Haseltine. The location of cis-acting regulatory sequences in the human $\mathrm{T}$ cell lymphotropic virus type III (HTLV-III/LAV) long terminal repeat. Cell 41:813-823 (1985).

17. Sodroski, J., C. A. Rosen, F. Wong-Staal, S. Z. Salahuddin, M. Popovic, S. Arya, R. C. Gallo, and W. A. Haseltine. Trans-acting transcriptional regulation of human T-cell leukemia virus type III long terminal repeat. Science (Washington D. C.) 227:171-173 (1985).

18. Hsu, M.-C., D. Schutt, M. Holly, L. W. Slice, M. I. Sherman, D. D. Richman, M. J. Potash, and D. J. Volsky. Inhibition of HIV replication in acute and chronic infections in vitro by a tat antagonist. Science (Washington D. C.) 254:1799-1802 (1991).

19. Witvrouw, M., R. Pauwels, A.-M. Vandamme, D. Schols, D. Reymen, N. Yamamoto, J. Desmyter, and E. De Clercq. Cell type-specific anti-human immunodeficiency virus type 1 activity of the transactivation inhibitor Ro5-3335. Antimicrob. Agents Chemother. 36:2628-2633 (1992).

20. Rosen, C. A., J. G. Sodroski, K. Campbell, and W. A. Haseltine. Construction of recombinant murine retroviruses that express the human T-cell leukemia virus type II and human T-cell lymphotropic virus type III trans activator genes. J. Virol. 57:379-384 (1985).

21. Maio, J. J., and F. L. Brown. Regulation of expression driven by human immunodeficiency virus type 1 and human T-cell leukemia virus type I long terminal repeats in pluripotential human embryonic cells. J. Virol. 62:1398-1407 (1988).

22. Berger, J., J. Hauber, R. Hauber, R. Geiger, and B. Cullen. Secreted placental alkaline phosphatase: a powerful new quantitative indicator of gene expression in eukaryotic cells. Gene 66:1-10 (1988).

23. Clavel, F., and P. Charneau. Fusion from without directed by human immunodeficiency particles. J. Virol. 68:1179-1185 (1994).

24. Sambrook, J., E. F. Fritsch, and T. Maniatis. Expression of cloned genes in cultured mammalian cells, in Molecular Cloning: A Laboratory Manual, 2nd ed. Cold Spring Harbor Laboratory, Cold Spring Harbor, NY (1989).

25. Hershfield, M. S., V. N. Aiyar, R. Premakumar, and W. C. Small. SAdenosylhomocysteine hydrolase from human placenta: affinity purification and characterisation. Biochem. J. 230:43-52.

26. Pauwels, R., E. De Clercq, J. Desmyter, J. Balzarini, P. Goubau, P. Herdewijn, H. Vanderhaeghe, and M. Vandeputte. Sensitive and rapid assay on MT-4 cells for the detection of antiviral compounds against the AIDS virus. J. Virol. Methods 16:171-185 (1987).

27. Pauwels, R., J. Balzarini, M. Baba, R. Snoeck, D. Schols, P. Herdewijn, J. Desmyter, and E. De Clercq. Rapid and automated tetrazolium-based colorimetric assay for the detection of anti-HIV compounds. J. Virol. Methods 20:309-321 (1988).
28. Reed, L. J., and H. Muench. A simple method of estimating fifty percent endpoints. Am. J. Hyg. 27:493-497 (1938).

29. Perno, C. F., A. Bergamini, C. D. Pesce, G. Milanese, M. Capozzi, S. Aquaro, S. Thaisrivongs, W. G. Tarpley, G. Zon, C. D'Agostini, G. Rocchi, E. Garaci, and R. Calió. Inhibition of the protease of human immunodeficiency virus blocks replication and infectivity of the virus in chronicallyinfected macrophages. J. Infect. Dis. 168:1148-1156 (1993).

30. Perno, C. F., and R. Yarchoan. Culture of HIV in monocytes and macrophages, in J. E. Coligan, A. H. Kruisbeck, D. H. Margulies, E. M. Sherwach, W. Strober, editors. Current Protocols in Immunology. Wiley, New York, 12.4.1-12.4.11 (1993).

31. Jonckheere, H., K. De Vreese, Z. Debyser, J. Vanderkerckhove, J. Balzarini, J. Desmyter, E. De Clercq, and J. Anné. A two plasmid co-expression system in Escherichia coli for the production of virion-like reverse transcriptase of the human immunodeficiency virus type 1. J. Virol. Methods 61:113-125 (1996).

32. Perno, C. F., S. Aquaro, B. Rosenwirth, E. Balestra, P. Peichl, A. Billich, N. Villani, and R. Calió. In vitro activity of inhibitors of late stages of the replication of HIV in chronically infected macrophages. J. Leuk. Biol. 56:381-386 (1994).

33. Newstein, M., E. J. Stanbridge, G. Casey, and P. R. Shank. Human chromosome 12 encodes a species-specific factor which increases human immunodeficiency virus type 1 Tat-mediated transactivation in rodent cells. J. Virol. 64:4565-4567 (1990).

34. Gaynor, R. Cellular transcription factors involved in the regulation of HIV-1 gene expression. AIDS 6:347-363 (1992).

35. Kingsman, S. M, and A. J. Kingsman. The regulation of human immunodeficiency virus type-1 gene expression. Eur. J. Biochem. 240:491-507 (1996).

36. Ueland, P. M. Pharmacological and biochemical aspects of S-adenosylhomocysteine and S-adenosylhomocysteine hydrolase. Pharmacol. Rev. 34: 223-253 (1982).

37. Chiang, P. K, and G. A. Miura. S-Adenosylhomocysteine hydrolase, in Biological Methylation and Drug Design (R. T. Borchardt, C. R. Creveling, and P. M. Ueland, eds.). Humana Press, Clifton, NJ, 239-251 (1986).

38. Bennett, L. L., Jr., R. W. Brockman, P. W. Allan, L. M. Rose, and S. C. 음 Shaddix. Alterations in nucleotide pools induced by 3 -deazaadenosine and related compounds: role of adenylate deaminase. Biochem. Pharmacol. 37:1233-1244 (1988).

39. Prus, K. L., G. Wolberg, P. M. Keller, J. A. Fyfe, C. R. Stopford, and T. P. e Zimmerman. 3-Deazaadenosine 5'-triphosphate: a novel metabolite of 3deazaadenosine in mouse leukocytes. Biochem. Pharmacol. 38:509-517 (1989).

Send reprint requests to: Dirk Daelemans, Rega Institute for Medical Research, Minderbroedersstraat 10, B-3000 Leuven, Belgium. E-mail: dirk.daelemans@uz.kuleuven.ac.be 